\title{
DIGESTATE IS EQUAL OR A BETTER ALTERNATIVE TO MINERAL FERTILIZATION OF KOHLRABI
}

\author{
T. Lošák, L. Musilová, A. Zatloukalová, M. Szostková, J. Hlušek, J. Fryč, T. Vítěz, \\ M. Haitl, E. Bennewitz, A. Martensson
}

Received: October 31, 2011

\begin{abstract}
LOŠÁK, T., MUSILOVÁ, L., ZATLOUKALOVÁ, A., SZOSTKOVÁ, M., HLUŠEK, J., FRYČ, J., VÍTĚZ, T, HAITL, M., BENNEWITZ, E., MARTENSSON, A.: Digestate is equal or a better alternative to mineral fertilization of kohlrabi. Acta univ. agric. et silvic. Mendel. Brun., 2012, LX, No. 1, pp. 91-96

In a one-year vegetation pot experiment, we compared the effect of digestate from a biogas station and mineral fertilisers on yield and quality parameters of kohlrabi, variety Segura Fl. Four treatments were used in the trial: 1) untreated control, 2) urea, 3) digestate, 4) urea, triple super phosphate, $\mathrm{KCl}$, $\mathrm{MgSO}_{4}$. The $\mathrm{N}$ dose was the same in treatments 2-4, $1.5 \mathrm{~g} \mathrm{~N} /$ pot. In treatment 4 the $\mathrm{P}, \mathrm{K}$ and $\mathrm{Mg}$ doses corresponded to those supplied in the digestate treatment (3).

The weight of single kohlrabi bulbs in the unfertilised control was significantly lower (36.2\%) than in the urea treatment (100\%) and the other fertilised treatments. After application of digestate (treatment 3 ) and mineral fertilisers (treatment 4), the weight of single bulbs significantly increased by 36.2 and $33.6 \%$, respectively, compared with the urea treatment (2). The content of ascorbic acid did not differ between the fertilised treatments $(282-301 \mathrm{mg} / \mathrm{kg})$, but was significantly lower than in the unfertilised control $(334 \mathrm{mg} / \mathrm{kg})$. There were significant differences between all fertilised treatments $(2,3,4)$ in bulb nitrate content $\left(745,187,462 \mathrm{mg} \mathrm{NO}_{3}^{-} / \mathrm{kg}\right.$ fresh matter, respectively). After digestate application the content decreased significantly, to $187 \mathrm{mg} \mathrm{NO}_{3}^{-} / \mathrm{kg}$ fresh matter. The soil $\mathrm{N}_{\text {min }}$ content after harvest varied between $4.19-5.79 \mathrm{mg} / \mathrm{kg}$ in all fertilised treatments and the $\mathrm{N}_{-} \mathrm{NH}_{4}^{+}$form prevailed over $\mathrm{N}_{-} \mathrm{NO}_{3}{ }^{-}$only in the digestate treatment $(3.45 / 2.34 \mathrm{mg} / \mathrm{kg})$. We recommend the use of digestate to kohlrabi as it results in comparable or better yield and qualitative parameters of kohlrabi compared with mineral fertilizers.
\end{abstract}

ascorbic acid, mineral fertilizers, mineral nitrogen, nitrate, yields, urea

Biogas and digestate are the end-products of anaerobic digestion of organic raw material, which is an important source of renewable energy. Anaerobic digestion has been known for centuries, but rising prices of fossil fuel and increasing atmospheric pollution have boosted the interest in this process over recent years (Holm-Nielsen et al., 2009; Weiland, 2010) and have made anaerobic digestion attractive to investors and consumers (Midillia et al., 2006; Angelidaki et al., 2011).

However, wide-scale biogas production raises a number of new questions, including the subsequent use of anaerobic fermentation residues
- digestate (Cigánek et al., 2010). Field and pot trials to date report positive effects of digestate application to arable land in terms of yield (Stinner et al., 2008; Arthurson, 2009; Gunnarsson et al., 2010) or no significant effects (Ross et al., 1989; Bath and Elfstrand, 2008). Expert opinion is divided on the properties and possibilities for practical use of digestate as an organic fertiliser (Odlare et al., 2008; Kolář et al., 2008, 2010; Möller et al., 2010, 2011; Lošák et al., 2011). Digestion is associated with large losses of organic C (Möller, 2009). During the digestion process, $24-80 \%$ of organic dry matter is transformed to methane and carbon dioxide (Amon 
and Döhler, 2004). However, the digestate produced is rich in $\mathrm{N}$ and has a high $\mathrm{NH}_{4}^{+}-\mathrm{N}$ /total $\mathrm{N}$ ratio, making it potentially suitable as a fertiliser.

The aim of this study was to compare the effectiveness of digestate and mineral fertilisers on yield and qualitative parameters of kohlrabi and to determine changes in post-harvest soil mineral nitrogen.

\section{MATERIALS AND METHODS}

The pot experiment was established on 20 May 2011; Mitscherlich vegetation pots were filled with $6 \mathrm{~kg}$ of medium heavy soil characterised as fluvial soil, the agrochemical properties of which are summarised in Table I. The experiment involved four treatments, as shown in Table II.

The digestate ( $\mathrm{C} / \mathrm{N}$ ratio $4: 1)$ was obtained from a biogas station which uses pig slurry (approx. 10 t/day) and maize silage from hybrid KWS 1393 (approx. $16 \mathrm{t} /$ day) as the input raw material. Prior to the experiment, the digestate was analysed for content of nutrients (Table III) and hazardous elements (Table IV). The contents of all hazardous elements (Cd, $\mathrm{Pb}, \mathrm{Hg}$, As, $\mathrm{Cr}, \mathrm{Cu}, \mathrm{Mo}, \mathrm{Ni}, \mathrm{Zn}$ ) were below the limit specified in EU Regulation 271/2009 Coll.

Mineral fertilisers and digestate were applied during watering as solutions and were thoroughly mixed with the entire amount of soil in the pot, with 4 replicate pots per treatment. Two seedlings of kohlrabi variety Segura Fl were planted per pot 10 days after fertilisation. The pots were watered to a level of $60 \%$ of the maximum water-holding capacity and were kept free of weeds. The bulbs were harvested at full maturity on 19 July 2011. Immediately after harvest, individual bulbs without leaves were weighed. Nitrate concentration (mg $\mathrm{NO}_{3}{ }^{-} / \mathrm{kg}$ ) in the fresh matter of bulbs was determined with a potentiometer using ion selective electrode (ISE). The content of ascorbic acid was determined in fresh matter using the capillary isotachophoresis method.

The results were processed statistically using variance analysis, followed by testing according to Scheffe $(\mathrm{P}<0.05)$.

\section{RESULTS AND DISCUSSION}

\section{a) Weight of single bulbs}

A characteristic of kohlrabi is high uptake of $\mathrm{N}$ from the soil (Feller and Fink, 1997), and therefore deficiency of $\mathrm{NO}_{3}-\mathrm{N}$ in the soil reduces yields (Steingrobe and Schenk, 1991). Sharof and Wier (1994) studied the minimum amount of $\mathrm{N}$ required for vegetable crops, including kohlrabi, in relation to components of $\mathrm{N}$ balance in the soil and found that $\mathrm{N}$ requirements were invariably lower than values from field trials.

As early as the first stages of growth in this pot study, there was a visible difference between the fertilised treatments and the unfertilised control. The plants in the latter had a lighter colour and growth of the aboveground biomass was markedly slower. At harvest, symptoms of $\mathrm{P}$ deficiency (violet discolouration) were detected on bulbs of the control treatment, which was the result of low $\mathrm{P}$ supply to the soil and unsuitable $\mathrm{pH}$ value for $\mathrm{P}$ uptake.

Weight of single bulbs is shown in Table V. The weight of the unfertilised bulbs (treatment 1) was 63.8\% lower than in the treatment fertilised with nitrogen only (2). This confirms that $\mathrm{N}$ was the

I: Agrochemical characteristics of the soil prior to trial establishment (Mehlich III)

\begin{tabular}{|c|c|c|c|c|}
\hline \multirow{2}{*}{$\mathrm{pH} / \mathrm{CaCl}_{2}$} & \multicolumn{4}{|c|}{$\mathrm{mg} / \mathrm{kg}$} \\
\hline & $\mathbf{P}$ & $\mathbf{K}$ & $\mathrm{Ca}$ & Mg \\
\hline 7.5 & 34 & 159 & 6,262 & 303 \\
\hline alkali & low & satisfactory & very high & good \\
\hline
\end{tabular}

II: Experimental set up to study the effect of digestate and mineral fertilization on kohlrabi

\begin{tabular}{cccc}
\hline Treatment No. & Description & $\begin{array}{c}\text { Dose of nutrients (g/pot): } \\
\text { N-P-K-Mg }\end{array}$ & Fertiliser used \\
\hline 1 & Untreated control & 0 & - \\
2 & $\mathrm{~N}$ & 1.5 & urea \\
3 & Digestate & $1.5-0.18-0.69-0.08$ & digestate \\
4 & $\mathrm{~N}, \mathrm{P}, \mathrm{K}, \mathrm{Mg}$ & $1.5-0.18-0.69-0.08$ & urea, triple superphosphate, $\mathrm{KCl}_{\mathrm{MgSO}} \mathrm{MgS}_{4}$ \\
\hline
\end{tabular}

III: Nutrient content of the digestate used for studying responses of kohlrabi

\begin{tabular}{|c|c|c|c|c|c|}
\hline \multirow{2}{*}{$\%$} & \multicolumn{5}{|c|}{ Nutrients } \\
\hline & $\mathbf{N}$ & $\mathbf{P}$ & K & $\mathrm{Ca}$ & Mg \\
\hline in dry matter (DM) & 11.4 & 1.37 & 5.2 & 2.02 & 0.62 \\
\hline
\end{tabular}


IV: Contents of metals in the digestate used for studying responses of kohlrabi and maximum admissible amounts

\begin{tabular}{lcccccccccc}
\hline & \multicolumn{10}{c}{$\mathbf{c}$ mg/kg dry matter } \\
\cline { 2 - 10 } & $\mathbf{C d}$ & $\mathbf{P b}$ & $\mathbf{H g}$ & $\mathbf{A s}$ & $\mathbf{C r}$ & $\mathbf{C u}$ & $\mathbf{M o}$ & $\mathbf{N i}$ & $\mathbf{Z n}$ \\
\hline Content & 0.1 & 2.4 & 0.2 & 0.2 & 9.1 & 99 & 4.6 & 8.6 & 481 \\
Max.* & 2 & 100 & 1 & 20 & 100 & 250 & 20 & 50 & 1,200 \\
\hline
\end{tabular}

*maximal admissible amount according to EU Regulation 271/2009 Coll.

V: The effect of digestate and mineral fertilizer on kohlrabi bulb weights

\begin{tabular}{ccrr}
\hline \multirow{2}{*}{ Treatment No. } & Description & \multicolumn{2}{c}{ Weight of one bulb } \\
\cline { 2 - 4 } & & g & 36.2 \\
2 & Untreated control & $116 \mathrm{~b}$ & 100.0 \\
3 & $\mathrm{~N}$ & $158 \mathrm{c}$ & 136.2 \\
4 & Digestate & $155 \mathrm{c}$ & 133.6 \\
\hline
\end{tabular}

Different letters $(\mathrm{a}, \mathrm{b}, \mathrm{c})$ indicate significant differences between treatments

VI: The effect of digestate and mineral fertilizer on content of ascorbic acid and nitrate in kohlrabi

\begin{tabular}{|c|c|c|c|c|c|}
\hline \multirow{2}{*}{ Treatment No. } & \multirow{2}{*}{ Description } & \multicolumn{2}{|c|}{ Content of ascorbic acid } & \multicolumn{2}{|c|}{ Nitrate content } \\
\hline & & mg/kg FM & rel. $\%$ & mg/kg FM & rel. $\%$ \\
\hline 1 & Untreated control & $334 \mathrm{~b}$ & 118.4 & $63 \mathrm{a}$ & 8.5 \\
\hline 3 & Digestate & $301 \mathrm{a}$ & 106.7 & $187 \mathrm{~b}$ & 25.1 \\
\hline 4 & $\mathrm{~N}, \mathrm{P}, \mathrm{K}, \mathrm{Mg}$ & $291 \mathrm{a}$ & 103.2 & $462 \mathrm{c}$ & 62.0 \\
\hline
\end{tabular}

FM - fresh matter; Different letters $(a, b, c)$ indicate significant differences between treatments

decisive element in terms of yield, as reported previously by Hlušek et al. (2002) and Feller and Fink (1997). The weight of single bulbs fertilised with the digestate (treatment 3) and with mineral fertilisers (treatment 4) was significantly higher, by 36.2 and $33.6 \%$ respectively, than the weight of those fertilised with nitrogen only (treatment 2). There was thus an obvious positive synergistic effect of additional nutrients (especially $\mathrm{P}, \mathrm{K}, \mathrm{Mg}$ ) on yield in treatments 3 and 4. No significant differences were observed between treatments 3 and 4. In experiments lasting several years, Stinner et al. (2008) also reported positive effects of three different types of digestate (fermented clover-grass mixture, cover crops and post-harvest residues) on wheat yields. Similarly, Bath and Elfstrand (2008) reported higher yields of leek after the application of digestate compared with fertilisation with compost. On soil with a low or satisfactory supply of available nutrients, Cigánek et al. (2010) discovered that grain yield of winter wheat increased by 30.0-63.9\% and seed yield of winter rape by $38.5-57.7 \%$ compared with the unfertilised control.

\section{b) Content of ascorbic acid and nitrate in bulbs}

Vitamin C, including ascorbic acid and dehydroascorbic acid, is one of the most important nutritional quality factors in many horticultural crops and has many biological activities in the human body. The content of vitamin $\mathrm{C}$ in vegetables can be influenced by various factors such as genotypic differences, pre-harvest climate conditions and cultural practices, maturity and harvesting method, and post-harvest handling procedures (Lee and Kader, 2000).

Table VI shows the contents of ascorbic acid and nitrate in the kohlrabi bulbs. The content of ascorbic acid did not differ between the fertilised treatments (282-301 mg/kg), but it was significantly lower than in the unfertilised treatment (334 mg/ $\mathrm{kg}$ ). Previous studies differ in their conclusions regarding the effect of nitrogenous fertilisation on the content of vitamin C. Mozafar (1993) reported that nitrogen fertilisers, especially at high rates, seem to decrease the concentration of vitamin C in many different vegetables. Similarly, according to Smatanová et al. (2004), the content of ascorbic acid in spinach decreased from 57.5 to $51.9 \mathrm{ppm}$ when the rate of nitrogen increased from 0.6 to $0.9 \mathrm{~g} \mathrm{~N} /$ pot. In contrast, Nilsson (1980) reported that nitrogen fertilisation did not affect the content of vitamin C in cauliflower, while Maurya et al. (1992) showed that with a higher dose of nitrogen, cauliflower contained significantly more vitamin C.

Kohlrabi is a vegetable prone to a higher risk of nitrate accumulation in tissues (Hlušek et al., 2002). The concentration of $\mathrm{NO}_{3}^{-}$in plants is affected primarily by species-specific factors, level of $\mathrm{N}$ fertilisation, the plant organ in question, growth stage and the $S$ concentration in the tissues (Marschner, 2002; Lošák et al., 2008). 
VII: The effect of digestate and mineral fertilizer on content of mineral nitrogen $\left(N_{\min }\right)$ in the soil after harvesting kohlrabi

\begin{tabular}{ccccc}
\hline \multirow{2}{*}{ Treatment No. } & Description & \multicolumn{3}{c}{$\mathbf{m g} / \mathbf{k g ~ D M}$} \\
\cline { 3 - 5 } & Untreated control & $\mathbf{N}_{\mathbf{N} \mathbf{N H}_{\mathbf{4}}{ }^{+}}$ & $\mathbf{N}-\mathbf{N O}_{\mathbf{3}}{ }^{-}$ & $\mathbf{N}_{\text {min }}$ \\
\hline 1 & $\mathrm{~N}$ & 2.30 & 2.11 & $3.41 \mathrm{a}$ \\
2 & Digestate & 3.12 & 2.31 & $4.44 \mathrm{~b}$ \\
3 & $\mathrm{~N}, \mathrm{P}, \mathrm{K}, \mathrm{Mg}$ & 2.06 & 2.34 & $5.79 \mathrm{c}$ \\
4 & & & 2.13 & $4.19 \mathrm{~b}$ \\
\hline
\end{tabular}

Different letters $(a, b, c)$ indicate significant differences between treatments

The lowest nitrate content was observed in the unfertilised control (63 $\mathrm{mg} / \mathrm{kg} \mathrm{FM})$ and the second lowest in the digestate treatment $(187 \mathrm{mg} /$ kg FM) (Table VI). The reason could be that the digestate contains a specific proportion of organic $\mathrm{N}(25-50 \%)$, which is subject to mineralisation after a certain period (Kirchmann and Witter, 1992). It can be assumed that during the short period of kohlrabi growth (approx. 7 weeks), only part of the organically bound nitrogen was mineralised Therefore mineral $\mathrm{N}-\mathrm{NH}_{4}{ }^{+}$from the digestate (or after its nitrification $\mathrm{N}-\mathrm{NO}_{3}{ }^{-}$) was available to the plants and was sufficient for yield formation, but did not increase the nitrate content in the bulbs. The nitrate content was highest in the two treatments fertilised with nitrogen in the form of urea $(745 \mathrm{mg} /$ $\mathrm{kg}$ of FM in treatment 2 and $462 \mathrm{mg} / \mathrm{kg}$ of FM in treatment 4). Urea is a readily soluble mineral fertiliser and plants can take up $\mathrm{N}$ from urea in the form of whole molecules or after decomposition as $\mathrm{NH}_{4}^{+}$or $\mathrm{NO}_{3}^{-}$(Mengel and Kirkby, 2001).

\section{c) Content of soil mineral nitrogen after harvest}

Nitrogen is the nutrient that is most susceptible to transformations affecting its availability to plants. These transformations include mineralisation, immobilisation, nitrification and denitrification, as well as leaching and ammonia volatilisation (Möller and Stinner, 2009). It is difficult to synchronise the supply of $\mathrm{N}$ from organic manures with the demands of crops for N (Pang and Letey, 2000). Soil microbial activity leads to $\mathrm{N}$ release that is not in synchronisation with plant nutrient demand (Dosch and Gutser, 1996). The elevated $\mathrm{NH}_{4}^{+}-\mathrm{N}$ concentration in the digestate used in this study indicates its potential suitability as a readily available $\mathrm{N}$ source.

The post-harvest content of $\mathrm{N}_{\min }$ in soil was lowest in the unfertilised treatment $(3.41 \mathrm{mg} / \mathrm{kg}$ ) (Table VII). Small but significant differences in the total content of $\mathrm{N}_{\text {min }}(4.19-5.79 \mathrm{mg} / \mathrm{kg})$ were observed among the other treatments. However, a great difference was observed in the forms of $\mathrm{N}$ present. $\mathrm{N}-\mathrm{NH}_{4}{ }^{+}$prevailed over $\mathrm{N}-\mathrm{NO}_{3}{ }^{-}$only in the digestate treatment $(3.45 / 2.34 \mathrm{mg} / \mathrm{kg})$, which had the highest $\mathrm{N}_{\min }$ content. Digestate has a large proportion of organically bound $\mathrm{N}$ (50-75\%), which is available only after mineralisation, i.e. by ammonification and nitrification (Kirchmann and Witter, 1992). Nonetheless the results indicate that within the short duration of the experiment, only a minor amount of $\mathrm{N}$ was nitrified. For the plants to utilise more $\mathrm{N}$ from the digestate, a longer time period would be necessary.

\section{SUMMARY}

The results of this one-year trial show that the digestate fertiliser used produced kohlrabi bulbs of a similar weight to those produced in the mineral fertiliser treatments, indicating comparable rates of nutrient supply. In terms of qualitative parameters, all fertilisation with $\mathrm{N}$ reduced the ascorbic acid content in bulbs by about 9.9-15.6\% compared with the unfertilised control. However, the nitrate content in bulbs was 2.5-4 times lower in digestate-fertilised bulbs than in both mineral-fertilised treatments. The post-harvest content of $\mathrm{N}_{\min }$ in the soil was higher after digestate application than in the urea-fertilised treatments and $\mathrm{N}-\mathrm{NH}_{4}{ }^{+}$prevailed over $\mathrm{N}-\mathrm{NO}_{3}{ }^{-}$. Application of digestate can therefore replace mineral fertilisers in kohlrabi production, providing great cost savings. However digestates are poor in labile organic substances and the soil must be supplied these from other sources.

\section{Acknowledgement}

This study was financed by the Internal Grant Agency of the Faculty of Agronomy MENDELU in Brno No. TP 9/2011 and by the Research plan No. MSM6215648905 'Biological and technological aspects of sustainability of controlled ecosystems and their adaptability to climate change', which is financed by the Ministry of Education, Youth and Sports of the Czech Republic. 


\section{REFERENCES}

AMON, T. and DÖHLER, H. 2004: Qualität und Verwendung des Gärrestes. In: Fachagentur Nachwachsende Rohstoffe e.V. (ed.) Handreichung-Biogasgewinnung und -nutzung, KTBL, Darmstadt, pp 153-165.

ANGELIDAKI, I., KARAKASHEV, D., BATSTONE, D. J., PLUGGE, C. M. and STAMS, A. J. M., 2011: Biomethanation and its potential. Methods in Enzymology, 494: 327-35l.

ARTHURSON, V., 2009: Closing the global energy and nutrient cycles through application of biogas residue to agricultural land-potential benefits and drawbacks. Energies, 2: 226-242.

BATH, B. and ELFSTRAND, S., 2008: Use of red clover-based green manure in leek cultivation. Biological Agriculture \& Horticulture, 25: 269-286.

CIGÁNEK, K., LOŠÁK, T., SZOSTKOVÁ, M. ZATLOUKALOVÁ,A., PAVLÍKOVÁ, D., VÍTĚZ, T., FRYČ, J. and DOSTÁL, J., 2010: Ověření účinnosti hnojení digestáty z bioplynových stanic na výnos ozimé řepky a ozimé pšenice. Agrochémia, 50: 1621. (in Czech with English abstract).

DOSCH, P. and GUTSER, R., 1996: Reducing N losses $\left(\mathrm{NH}_{3}, \mathrm{~N}_{2} \mathrm{O}, \mathrm{N}_{2}\right)$ and immobilization from slurry through optimized application techniques. Fertilizer Research, 43: 165-171.

FELLER, C. and FINK, M., 1997: Nitrogen uptake of kohlrabi, estimated by growth stages and an empirical growth model. Journal of Plant Nutrition and Soil Science, 160: 589-594.

GUNNARSSON, A., BENGTSSON, F. and CASPERSEN, S., 2010: Use efficiency of nitrogen from biodigested plant material by ryegrass. Journal of Plant Nutrition and Soil Science, 173: 113-119.

HLUŠEK, J., RICHTER, R. and RYANT, P., 2002: Výživa a hnojení zahradních plodin. 1. ed. Praha, Zemědělec, 8lp. (in Czech).

HOLM-NIELSEN, J. B., SEADI, T. AL. and OLESKOWICZ-POPIEL, P., 2009: The future of anaerobic digestion and biogas utilization. Bioresource technology, 100: 5478-5484.

KIRCHMANN, H. and WITTER, E., 1992: Composition of fresh aerobic and anaerobic farm animal dungs. Bioresource Technology, 40: 137-142.

KOLÁŘ, L., KUŽEL, S., PETERKA, J., ŠTINDL, P. and PLÁT, V., 2008: Agrochemical value of organic matter of fermenter wastes in biogas production. Plant, Soil and Environment, 54: 321-328.

KOLÁŘ, L., KUŽEL, S., PETERKA, J., and BOROVÁBATT, J., 2010: Agrochemical value of the liquid phase of wastes from fermenters during biogas production. Plant, Soil and Environment, 56: 23-27.

LEE, S. K. and KADER, A. A., 2000: Preharvest and postharvest factors influencing vitamin $\mathrm{C}$ content of horticultural crops. Postharvest Biology and Technology, 20: 207-220.

LOŠÁK, T., HLUŠEK, J., KRÁČMAR, S. and VARGA, L., 2008: The effect of nitrogen and sulphur fertilization on yield and quality of kohlrabi
(Brassica oleracea, L.). Revista Brasileira de Ciencia do Solo, 32: 697-703.

LOŠÁK, T., ZATLOUKALOVÁ, A., SZOSTKOVÁ, M., HLUŠEK, J., FRYČ, J., VÍTĚZ, T., 2011: Comparison of the effectiveness of digestate and mineral fertilisers on yields and quality of kohlrabi (Brassica oleracea, L.). Acta Universitatis Agriculturae et Silviculturae Mendelianae Brunensis, LIX, 3: 117122.

MARSCHNER, H., 2002: Mineral nutrition of higher plants. 2nd edition. London: Academic Press, 889 p. MAURYA, A. N., CHAURASIA, S. N. S. and REDDY, Y. R. M., 1992: Effect of nitrogen and molybdenum levels on growth, yield and quality of cauliflower (Brassica oleracea var. Botrytis) cv. Snowball-16. Haryana Journal of Horticultural Sciences, 21: 232-235.

MENGEL, K. and KIRKBY, E. A., 2001: Principles of Plant Nutrition. $5^{\text {th }}$ Edition, Kluwer Academic Publishers, Dordrecht / Boston / London, 849 p.

MIDILLIA, A., DINCERB, I. and AYA, M., 2006: Green energy strategies for sustainable development. Energy Policy, 34: 3623-3633.

MÖLLER, K., 2009: Influence of different manuring systems with and without biogas digestion on soil organic matter and nitrogen inputs, flows and budget in organic cropping systems. Nutrient Cycling in Agroecosystems, 84: 179-202.

MÖLLER, K. and STINNER, W., 2009: Influence of different manuring systems with and without biogas digestion on soil mineral nitrogen content and on gaseous nitrogen losses (ammonia, nitrous oxides). European Journal of Agronomy, 30: 1-16.

MÖLLER, K., SCHULZ, R., MÜLLER, T., 2010: Substrate inputs, nutrient flows and nitrogen loss of two centralized biogas plants in southern Germany. Nutrient Cycling in Agroecosystems, 87: 307325.

MÖLLER, K., SCHULZ, R., MÜLLER, T., 2011: Effects of setup of centralized biogas plants on crop acreage and balances of nutrients and soil humus. Nutrient Cycling in Agroecosystems, 89: 303312.

MOZAFAR, A., 1993: Nitrogen fertilizers and the amount of vitamins in plants: a review. Journal of Plant Nutrition, 16: 2479-2506.

NILSSON, T., 1980: The influence of soil type, nitrogen and irrigation on yield, quality and chemical composition of cauliflower. Swedish Journal of Agricultural Research, 10: 65-75.

ODLARE, M., PELL, M. and SVENSSON, K., 2008: Changes in soil chemical and microbiological properties during 4 years of application of various organic residues. Waste Management, 28: 1246-1253.

PANG, X.P. and LETEY, J., 2000: Organic farming: challenge of timing nitrogen availability to crop nitrogen requirements. Soil Science Society of America Journal, 64: 247-253.

ROSS, D. J., TATE, K. R., SPEIR, T. W., STEWART, D. J. and HEWITT, A. E., 1989: Influence of biogas-digester effluent on crop growth and soil biochemical properties under rotational cropping. 
New Zealand Journal of Crop and Horticultural Science, 17: 77-87.

SHAROF, H. C. and WIER, U., 1994: Calculation of nitrogen immobilization and fixation. Gartenbau Hannover Germany. Bodenkunde, 157: 11-16.

SMATANOVÁ, M., RICHTER, R., HLUŠEK, J. 2004: Spinach and pepper response to nitrogen and sulphur fertilization. Plant, Soil and Environment, 50: 303-308.

STEINGROBE, G. and SCHENK, M. K., 1991: Influence of nitrate concentration at the root surface on yield and nitrate uptake of kohlrabi
(Brassica oleracea - gongyloides, L.) and spinach (Spinacia oleracea, L.). Plant and Soil, 135: 205-211.

STINNER, W., MÖLLER, K. and LEITHOLD, G., 2008.: Effects of biogas digestion of clover/grassleys, cover crops and crop residues on nitrogen cycle and crop yield in organic stockless farming systems. European Journal of Agronomy, 29: 125-134.

VYHLÁŠKA č. 474/2000 Sb., o stanovení požadavků na hnojiva, ve znění pozdějších předpisů. (in Czech).

WEILAND, P., 2010: Biogas production: current state and perspectives. Applied Microbiological Biotechnology, 85: 849-860.

Address

doc.Ing. TomášLošák, Ph.D.,Ing.Ludmila Musilová,Ing. AndreaZatloukalová,Mgr. Monika Szostková,Ph.D., prof. Ing. Jaroslav Hlušek, CSc., Ústav agrochemie, půdoznalství, mikrobiologie a výživy rostlin, doc. Ing. Jiř́i Fryč, CSc., Ing. Tomáš Vítěž, Ph.D., Ing. Martin Haitl, Ústav zemědělské, potravinářské a environmentální techniky, Mendelova univerzita v Brně, Zemědělská 1, 61300 Brno, Česká republika, Ing. Eduardo von Bennewitz, Ph.D., Department of Agronomy, Universidad Católica del Maule, Casilla 7-D, Curicó, Chile, prof. Anna Martensson, Department of Soil and Environment, Swedish University of Agricultural Sciences, Ulls väg 17, Ultuna, SE 75651 Uppsala, Sweden, e-mail: losak@mendelu.cz, ludmila.musilova@mendelu.cz, andrea.zatloukalova@mendelu.cz, szostkov@mendelu.cz, hlusek@mendelu.cz, fryc@mendelu.cz, vitez@ mendelu.cz,martin.haitl@mendelu.cz,evon@ucm.cl, anna.martensson@slu.se 